\title{
Den dramatiske
}

\section{poesi}

\section{G. W. F. Hegel}

1

Dramaet må betragtes som poesiens og kunstens højeste trin overhovedet, fordi det både efter sit indhold og efter sin form udvikler sig til den mest fuldendte totalitet. For over for de øvrige sanselige materialer, sten, træ, farve, tone, er talen det eneste element, der er værdigt til en eksposition af ånden, og blandt talekunstens særegne arter er den dramatiske poesi atter den, som i sig forener epossets objektivitet med lyrikkens subjektive princip, idet den fremstiller en i sig lukket handling som en virkelig og umiddelbart nutidig handling, der i lige så høj grad udspringer af den handlende karakters indre, som den i sit resultat er bestemt af hensigternes, individernes og kollisionernes substantielle natur. Denne formidling af det episke gennem subjektets inderlighed som en nutidig handlende person forhindrer imidlertid dramaet $i$ på en episk måde at beskrive den ydre side af lokalet, omgivelserne samt handlingerne og begivenhederne, og for at hele kunstværket kan blive levende på en sand måde, kræves der derfor den fuldstændige sceniske opførelse af det. Endelig er der selve handlingen, som $i$ totaliteten af sin indre og ydre virkelighed kan op- 
fattes på en simpelthen modsætningsfyldt måde, hvis gennemgribende princip i form af det tragiske og komiske gør artsforskellene inden for den dramatiske poesi til en tredje hovedside.

2

Dramaets trang overhovedet er fremstillingen af nutidige menneskelige handlinger og relationer for den forestillende bevidsthed gennem sproglige ytringer fra de personer, der foretager handlingen. Men den dramatiske handling begrænser sig ikke til den simple uhindrede gennemførelse af en bestemt hensigt, men beror simpelthen på kolliderende omstændigheder, lidenskaber og karakterer og fører derfor til aktioner og reaktioner, som nu på sin side atter gør en bilæggelse af kampen og striden nødvendig. Hvad vi derfor ser for os, er de hensigter, der er individualiserede til levende karakterer og konfliktrige situationer, i deres visen sig og hævden sig, gensidige indvirken på og bestemmen af hinanden - det hele i gensidige ytringers øjeblikkelighed - samt det i sig selv begrundede slutresultat af hele denne menneskelige drivkraft i villen og fuldbringen, som bevæget gennemkrydser sig selv og dog falder til ro.

Som jeg allerede har anført, skal den poetiske opfattelse af dette nye indhold nu være en formidlende forening af det episke og det lyriske kunstprincip. (...) Hvad der nu (...) angår selve formidlingen mellem det episke og det lyriske princip, så skal vi forestille os det på følgende måde.

Allerede eposset fører en handling frem for vore øjne, men som en substantiel totalitet af en national ånd i form af objektivt bestemte begivenheder og handlinger, hvori den subjektive villen, den individuelle hensigt og omstændighedernes yderlighed med deres virkelige forhindringer holder hinanden i ligevægt. I lyrikken er det derimod subjektet, som træder frem og udtaler sig i sin selvstændige inderlighed for sig.

\section{3}

Det første og mest almene, som lader sig fastlægge om dramaets enhed, knytter sig til de bemærkninger, som jeg allerede har an- 
tydet ovenfor, nemlig at til forskel fra eposset må den dramatiske poesi sammenfatte sig strengere i sig selv. For selv om eposset også har en individuel begivenhed som enhedspunkt, så foregår denne dog på en vidt udbredt grund af en bred folkevirkelighed og kan folde sig ud til mangesidige episoder og deres objektive selvstændighed. Et lignende skær af en kun løs sammenhæng var tilladt $\mathrm{i}$ enkelte arter af lyrik af helt andre årsager. Men da dette episke grundlag, som vi allerede har set, på den ene side nu falder bort $\mathrm{i}$ det dramatiske, og da individerne på den anden side ikke udtaler sig i ren lyrisk enkelthed, men gennem modsætningerne mellem deres karakterer og hensigter træder så meget i forhold til hinanden, at denne individuelle relation netop udgør grundlaget for deres dramatiske eksistens, så følger allerede heraf nødvendigheden af en fastere lukning af hele værket. Denne snævrere sammenhæng er såvel af objektiv som subjektiv natur: objektiv grundet det saglige indhold i de hensigter, som individerne kæmper for at gennemføre; subjektiv fordi dette i sig selv substantielle indhold i det dramatiske fremtræder som en lidenskab ved særegne karakterer, sådan at fiaskoen eller gennemførelsen, lykken eller ulykken, sejren eller undergangen nu væsentlig rammer individernes egne hensigter.

Som nærmere lovmæssigheder lader de velkendte forskrifter om stedets, tidens og handlingens enhed sig angive.

\section{4}

Hvad (...) angår den konkrete udfoldelsesmåde af det dramatiske kunstværk, så skal vi hovedsagelig fremhæve tre punkter, hvor dramaet adskiller sig fra eposset og digtet: nemlig omfanget, arten af forløbet og inddelingen i scener og akter.

Vi har allerede set, at et drama ikke behøver udvide sig til den samme bredde, som er nødvendig for den egentlige epopé. Udover det allerede omtalte bortfald af den i eposset i sin totalitet skildrede verdenstilstand og fremkomsten af den enklere kollision, som afgiver det væsentlige dramatiske indhold, vil jeg derfor kun anføre den yderligere grund, at hvad den episke digter må 
beskrive for anskuelsen i hvilende ro, bliver i dramaet pa den ene side overladt til den virkelige opførelse, mens det på den anden side ikke er den reale handlemåde, men ekspositionen af den indre lidenskab, der udgør hovedsagen. Men i modsætning til bredden af reale fremtrædelser så trækker det indre sig sammen til enkle følelser, sentenser, beslutninger osv. og gør til forskel fra den episke breden tingene ud og den kronologiske fortidighed også i denne henseende princippet om den lyriske koncentration og om den nutidige opståen og udtalen af lidenskaber og forestillinger gældende. Den dramatiske poesi nøjes dog ikke kun med fremlæggelsen af en enkelt situation, men fremstiller samtidig det usanselige ved sindet og ånden som en handlende totalitet af tilstande og hensigter hos forskelligartede karakterer, som tilsammen ytrer det, som med hensyn til deres handlinger foregår i deres indre, sådan at sammenlignet med det lyriske digt breder dramaet sig atter ud til et meget større omfang og afrunder sig. Alment lader forholdet sig bestemme således, at den dramatiske poesi cirka står i midten mellem epopeens udbredelse og lyrikkens sammentrukkethed.

Det samme princip, som gav os grundlaget for opdelingen af den dramatiske kunst $\mathrm{i}$ tragedie og komedie, leverer nu også de væsentlige holdepunkter for dens udviklingshistorie. For fremgangen $\mathrm{i}$ denne udfoldelse kan kun bestå i en adskillelse og udvikling af de hovedmomenter, som ligger $i$ begrebet om den dramatiske handlen, sådan at det substantielle $\mathrm{i}$ hensigterne, konflikterne og karaktererne på den ene side bliver understreget $\mathrm{i}$ hele opfattelsen og udførelsen, mens den subjektive inderlighed og partikularitet udgør midtpunktet på den anden side.

I denne henseende kan vi her, hvor det ikke drejer sig om en fuldstændig kunsthistorie, på forhånd stille de tilløb til en dramatisk kunst til side, som vi træffer på i Orienten. For uanset hvor langt den orientalske poesi end har bragt det i epos og enkelte arter af lyrik, så forbyder hele den morgenlandske verdensanskuelse fundamentalt en passende udvikling af den dramatiske kunst. For til den sande tragiske handlen er det nødvendigt, at princippet om den individuelle frihed og selvstændighed allerede 
er vågnet eller i det mindste den selvbestemmelse frit af sig selv at ville stå inde for sine egne handlinger og deres følger; og i endnu højere grad må subjektivitetens frie ret og dens selvbevidste herredømme have manifesteret sig for at komedien kan træde frem. Ingen af delene er tilfældet i Orienten, og især står den storslåede ophøjethed ved den muhammedanske poesi helt igennem fjernt fra ethvert forsøg på at udtale sig dramatisk, selv om den individuelle selvstændighed på den ene side allerede kan gøre sig energisk gældende i den, da den ene substantielle magt på den anden side kun endnu mere konsekvent underkaster hver levende skabning under sig og bestemmer deres lod med hensynsløse omskiftelser. Derfor kan der ikke her optræde berettigelsen af et særegentindhold i den individuelle handling og i den sig i sig selv fordybende subjektivitet, som den dramatiske kunst kræver det, ja subjektets underkastelse under guds vilje bliver netop desto mere abstrakt i muhammedsnismen, jo mere abstrakt-almen den ene herskende magt er, som står over det hele og sluttelig ikke lader nogen særegenhed komme frem. Derfor finder vi kun dramatiske tilløb hos kineserne og inderne, men at dømme efter de få prøver, som indtil nu er blevet kendt, er det dog heller ikke her som gennemførelse af en fri, individuel handlen, men mere kun som levendegørelse af begivenheder og følelser i bestemte situationer, som bliver fremført $i$ et nutidigt forløb.

Derfor skal vi søge den egentlige begyndelse på den dramatiske poesi hos grækerne, for hvem princippet om den frie individualitet for første gang overhovedet gjorde fuldendelsen af den klassiske kunstform mulig. Med hensyn til handlingen kan individet dog også inden for denne type kun træde frem, for så vidt som den frie livlighed af det substantielle indhold i de menneskelige hensigter kræver det. Hvad det derfor især drejer sig om i det gamle drama, tragedie og komedie, er det almene og væsentlige $\mathrm{i}$ de hensigter, som individerne fuldfører; i tragedien bevidsthedens sædelige ret med henblik på den bestemte handling, berettigelsen af gøremålet i og for sig; og i den gamle komedie er det i det mindste ligeledes de almene offentlige interesser, som bliver fremhævet: statsmændene og deres måde at styre staten på, krig og 
fred, folket og dets sædelige tilstande, filosofien og dens fordærvelse osv. Derfor kan hverken den mangfoldige skildring af det indre sind og den ejendommelige karakter endsige den specielle forvikling og intrige vinde fuldstændig plads her, eller interessen dreje sig om individernes skæbne, i stedet for disse partikulære sider bliver der snarere lagt vægt på frem for alt den medlevende interesse for den enkle kamp og sejr for de væsentlige livsmagter og for de guder, som hersker i menneskets bryst, som hvis individuelle repræsentanter de tragiske helte optræder, på samme måde som de komiske figurer gør den almene fordrejelse åbenbar, hvortil selv grundretningen i det offentlige liv har forvandlet sig i nutiden og virkeligheden.

I den moderne, romantiske poesi er den vigtigste genstand derimod den personlige lidenskab, hvis befrielse kun kan vedrøre en subjektiv hensigt, overhovedet skæbnen for et særegent individ og en særegen karakter under specielle forhold.

Ifølge denne opfattelse ligger den poetiske interesse $i$ formatet af de karakterer, som gennem deres fantasi eller sindelag og evner både viser sig at være hævet over deres situation og handlinger og viser den fulde rigdom i sindet som en real mulighed, der ofte kun er gået til grunde og forarmet gennem omstændigheder og forviklinger, men samtidigt selv igen bevarer en forsoning på grund af disse naturers format. Med hensyn til handlingens særegne indhold er det derfor ikke den sædelige berettigelse og nødvendighed, men den enkelte person og dennes anliggender, hvortil vor interesse er henvist ved denne opfattelsesmåde. Derfor leverer kærligheden, ærgerrigheden osv. et hovedmotiv ved dette standpunkt, ja selv forbrydelsen kan ikke udelukkes. Det sidstnævnte bliver dog let til et skær, hvor den dramatiske poesi kan lide skibbrud. For en forbryder i sig selv giver kun et ækelt indtryk, især når han er svag og fundamentalt er nederdrægtig som helten i Müllners ${ }^{1}$ Schuld. Frem for alt må her derfor som et mindstemål kræves, at karakteren har formatet og subjektiviteten har magten til at holde alt det negative ud og kunne bære deres lod uden at benægte deres handlinger og uden at blive knust i sig selv. Men omvendt kan de substantielle hensigter, fædreland, 
familie, krone og rige osv. på ingen måde holdes helt borte, selv om det for individerne $\mathrm{i}$ den forbindelse ikke kommer an på det substantielle, men på deres egen individualitet, men de danner så i helheden mere den bestemte grund, hvorpå individerne står med deres subjektive karakter og kommer i kamp, end at de leverer det egentlige ultimative indhold i villen og handlen.

Ved siden af denne subjektivitet kan der yderligere træde en bredde i partikulariteten såvel med henblik på et indre som også med hensyn til de ydre omstændigheder og forhold, inden for hvilke handlingen foregår. Til forskel fra de enkle konflikter, som vi finder dem hos de gamle, gør der sig her med ret gældende den mangfoldighed og fylde hos de handlende karakterer, sjældenheden i altid nyt sammenslyngede forviklinger, intrigernes irveje, det tilfældige $\mathrm{i}$ begivenhederne, overhovedet alle de sider hvis frisættelse over for den gennemgribende substantialitet i det væsentlige indhold betegner den romantiske kunstform som type til forskel fra den klassiske.

På trods af denne tilsyneladende ubundne partikularitet så må imidlertid på den ene side den bestemthed i kollisionen, som skal udkæmpes, også være synligt fremhævet på dette standpunkt, hvis det hele fortsat skal være dramatisk og poetisk, og på den anden side må hovedsageligt $\mathrm{i}$ tragedien gennem forløbet og udgangen af den særegne handling herredømmet for en højere verdensregering være åbenlys, det være sig som forsyn eller skæbne.

6.

Med komediens udviklingsarter er vi nu nået til den virkelige afslutning på vor videnskabelige undersøgelse. Vi begyndte med den symbolske kunst, hvori subjektiviteten kæmper for at finde sig som indhold og form og blive objektiv; vi skred videre til den klassiske skulptur, som fremstiller det substantielle, der er blevet klart for sig selv, som en levende individualitet for sig selv, og sluttede i sindets og inderlighedens romantiske kunst med den frit i sig selv sig åndeligt bevægende absolutte subjektivitet, der, befriet i sig selv, ikke mere forener sig med det objektive og særegne og bring- 
er sig det negative i denne opløsning til bevidsthed gennem komikkens humor. Men på dette højdepunkt fører komedien samtidig til opløsning af kunsten overhovedet. Hensigten med al kunst er den gennem ånden frembragte identitet, hvori det evige, guddommelige, i og for sig sande bliver åbenbaret $\mathrm{i}$ virkelig fremtrædelse og skikkelse for vor ydre erfaring, for sindet og forestillingen. Men hvis nu komedien kun fremstiller denne enhed i dens selvdestruktion, idet det absolutte, som vil bringe sig frem til realitet, ser selve denne virkeligg $ø$ relse $ø$ delagt af de interesser i virkelighedens element, der nu er blevet frit overladt til sig selv og kun er rettet mod det tilfældige og subjektive, så fremtræder det absoluttes nutid og virksomhed ikke mere i positiv forening med karaktererne og hensigterne i den virkelige tilværelse, men gør sig kun gældende i den negative form, at alt som ikke svarer til det absolutte ophæver sig, og kun subjektiviteten som sådan viser sig samtidig i denne opløsning som bevidst om sig selv og sikret i sig selv.

På denne måde har vi nu lige til afslutningen filosofisk ordnet enhver væsentlig bestemmelse af det skønne og kunstens formgivning til en krans, og at binde den hører til de mest værdige beskæftigelser, som videnskaben er i stand til at fuldende. For i kunsten har vi ikke blot at gøre med et behageligt eller nyttigt legeværk, men med åndens befrielse fra endelighedens indhold og former, med det absoluttes præsens og forsoning i det sanselige og fremtrædende, med en udfoldelse af sandheden, der ikke udtømmer sig som naturhistorie, men åbenbarer sig i verdenshistorien, hvoraf den selv udgør den skønneste side og den bedste løn for det hårde arbejde $\mathrm{i}$ det virkelige og erkendelsens sure møje. Derfor kunne vore betragtninger ikke bestå i en ren kritik af kunstværker eller en anvisning i at producere disse, men havde intet andet.mål end at forfølge det skønnes og kunstens grundbegreb gennem alle de stadier, som det gennemløber i sin realisation, og gennem tænkningen gøre det fatteligt og vise sandheden $\mathrm{i}$ det. Gid min fremstilling med henblik på dette hovedpunkt har ydet Dem fyldest, og hvis det bånd, som overhovedet var knyttet mellem os og til dette fælles formål, nu har opløst sig, 
så gid, dette er mit sidste ønske, at der i stedet er blevet knyttet et højere, ubrydeligt bånd af ideen om det skønne og sande, og at det fra nu af for evigt holder os fast forenet.

\section{Note:}

I. Adolf Müllner (1774-1829), dramatiker (note ved redaktionen af den tyske udgave).

Oversat af Lars Morell 
